\title{
DENSITY, CALORIFIC VALUE AND CLEAVAGE STRENGTH OF SELECTED HYBRID EUCALYPTS GROWN IN UGANDA
}

\author{
Harold Turinawe ${ }^{1, \star}$, Paul Mugabi², Mnason Tweheyo ${ }^{2}$
}

\begin{abstract}
This study was done to ascertain the suitability of Uganda's clonal eucalypts for fuelwood. The objectives were to determine: (i) basic density (BD); (ii) calorific value (CV); and (iii) cleavage resistance (CLR) parallel to the grain of widely adopted clones i.e. GU7, GU8, GC540, GC550 and GC796 and to compare these properties with those of their parent materials; i.e. Eucalyptus grandis, Eucalyptus cammaldulensis, and Eucalyptus urophylla. Tests were done according to BS373(1957) and ASTM:E870-82(2006) procedures. Clone GC540 showed the highest BD $\left(664 \mathrm{~kg} / \mathrm{m}^{3}\right)$, GU7 had the highest CV $(17800 \mathrm{~kJ} / \mathrm{kg})$, GU7 and GC540 had higher values for CLR $(20 \mathrm{~N} / \mathrm{mm})$. BD and CLR means were in-between parent material means for GC clones. All clones had lower values of $\mathrm{CV}$ compared to parent materials. It was concluded that clonal wood at 6-7 years remains a viable alternative for fuelwood due to high volume increment per unit time and moderate CLR values to allow ease of splitting.
\end{abstract}

Keywords: Hybrid Eucalypts, density, calorific value, cleavage resistance, Uganda.

\section{INTRODUCTION}

The rapid decrease in indigenous timber tree species coupled with the need for timber and other wood products, has necessitated Uganda to embark on a fast track in commercial forestry plantation development in order to meet the increasing demands. Clonal eucalypts has been proposed and is being prompted as one of the solutions to meet the need for forest products in the country. Thus clonal eucalypts have been introduced and are being promoted, for utility poles, timber and fuel wood. The clones are preferred for their fast growth and, therefore, shorter rotations compared to the traditional tree varieties (Oballa et al. 2005). At the time of their introduction in 2002, it was estimated that a stand of clonal eucalypts would provide fuel wood, construction or transmission poles, and industrial timber at 3-4, 4-6 and 7-8 years respectively (SPGS 2007, Epila-Otara 2004). Twelve eucalypt clones were introduced in Uganda in 2002 by the National Forest Resources Research Institute (NaFORRI) from Mondi owned forest plantations in South Africa under the Tree Biotechnology Project-Uganda. The introduced clones included 5 hybrids of Grandis $\times$ Urophylla (GUs), 6 hybrids of Grandis $\times$ Camaldulensis (GCs) and one pure Eucalyptus grandis hybrid (Epila-Otara 2004).

Based on the fact that the clonal eucalypts were initially developed in South Africa for superior growth and pulping characteristics; but were brought to Uganda mainly for supply of fire wood and poles (EpilaOtara 2004), it is not clear that the clones in Uganda would do the purpose there are intended for since it is a diversion form the original purpose in SA. This study aimed at ascertaining their suitability for the intended fuel wood use in Uganda. The specific objectives were to determine: (i) the density; (ii) the calorific value; and (iii) the cleavage resistance parallel to the grain of the most widely adopted clones 
i.e. GU7, GU8, GC540, GC550 and GC796 and to assess how these values compare with those of the parent species E. grandis, E. camaldulensis and E. Urophyla in terms of potential firewood potential. The results of our findings are important in helping forest farmers in Uganda on whether to adopt the growing of clones or maintain landrace Eucalyptus species. They are equally important in advising the parent company in SA on the diverse use of clones. It will also reduce pressure on the existing vegetation in Uganda since wood fuel is the leading cause of deforestation in Uganda.

\section{Study area and Methods}

\section{Study area}

Sample trees were selected from two ecological zones i.e. the Lake Victoria Crescent, and the Southern and Eastern Lake Kyoga Basin. The selected sites were Kifu in Mukono district and Ikulwe in Mayuge district representing the Lake Victoria Crescent, and Southern and Eastern Lake Kyoga basin agro-ecological zones respectively (Figure 1).

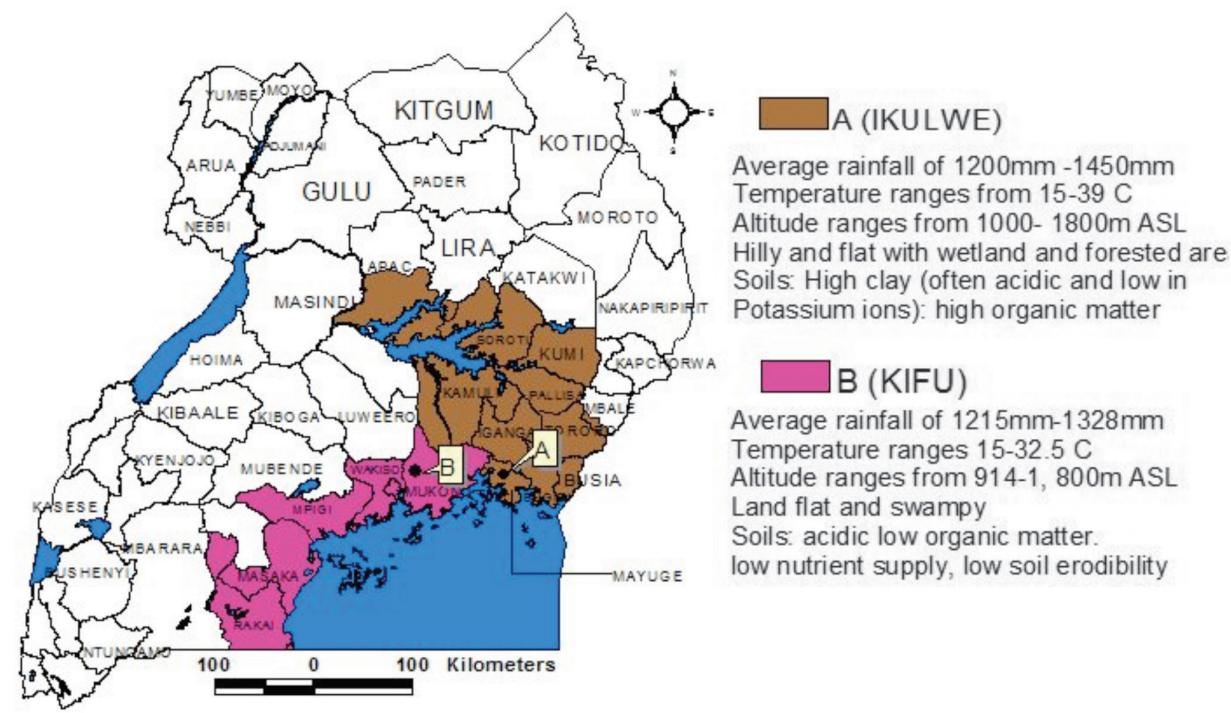

Figure 1. A map of Uganda showing location of trials sampled for this study.

\section{Sample selection}

The sites were selected because of the recorded acreage of clonal eucalypts planted in the different ecological zones at the time of study. The selected trials, Kifu and Ikulwe were of the same age, established between April and May 2002 (Epila-Otara and Ndhokero 2009). For each of the study clones, 5 individual trees were randomly selected. Each selected tree was felled, sectioned into three billets of $1,2 \mathrm{~m}$ long at breast height (1,3m), 45\% and $75 \%$ of the total tree height and labelled appropriately (Figure 2).

\section{Preparation of samples for transportation to the laboratory}

Each of the 1,2m billets was sawn using the through and through method to produce centre planks of $150 \mathrm{~mm}$ thickness following Lavers (1983). The centre pieces were machined to $80 \mathrm{~mm}$ thickness for easier seasoning and labelled to indicate the particular clone, position in the tree and ecological zone of origin. The pieces were air seasoned for 30 days and then reduced in size to $800 \times 60 \times 30 \mathrm{~mm}$. The specimens were dried to $25-30 \% \mathrm{MC}$ (Below fiber saturation point) and then machined further to the final size of $800 \times 20 \times 20 \mathrm{~mm}$ from which the test pieces were obtained (Figure 2). 


\section{Laboratory procedures}

Tests were carried out in accordance with British Standard, BS 373 (1957) and American Society for Testing Materials, ASTM E870-82(2006) procedures. The Tinius Olsen Model H50K-T universal material strength testing machine was used for the cleavage resistance tests while the Gallen Kamp adiabatic calorimeter was used for the heat value experiments. The Qmat professional software was used to obtain strength values from the crosshead. The MC for each specimen at the time of test was recorded.

\section{Basic density}

The test procedure was as specified by BS 373(1957). To obtain the green volume, test specimens were soaked overnight, removed and wiped. The water displacement method was then used to determine the green weight and thus volume based on the Archimedes's principle. The specimen was suspended by a needle clamped in a stand and then completely immersed in a beaker containing distilled water placed on a weighing balance set to zero reading. The weight of water displaced for each test specimen, which is equal to the green volume of the test piece was recorded. The test specimen was then oven dried at a temperature of $103+2^{\circ} \mathrm{C}$ until constant weight (in grams) and re-weighed to obtain oven dry weight. Basic density in $\mathrm{kg} / \mathrm{m}^{3}$ was calculated from relationship in equation 1.

$$
B D=\frac{W_{d} \times 1000}{v_{g}}
$$

Where;

$\mathrm{BD}=$ Basic density $\left(\mathrm{kg} / \mathrm{m}^{3}\right)$

$\mathrm{W}_{\mathrm{d}}=$ Oven dry weight of specimen $(\mathrm{g})$

$\mathrm{V}_{\mathrm{g}}=$ Green volume of specimen $\left(\mathrm{cm}^{3}\right)$

\section{Calorific Value}

The calorific value of wood was obtained directly from calorimetric tests using the Gallen Kamp adiabatic calorimeter. The procedure used was adopted from ASTM E870-82 (2006); only the samples obtained at breast height of the tree were used for this test. This was on assumption that samples obtained in the butt end of a tree have higher density values and, therefore, higher calorific values (Desch and Dinwoodie 1996) and would give characteristics representative for comparison with the parent materials. The specimens were mechanically broken down to wood mill and packaged into well indexed dispensing envelopes. From each envelope, 0,5-1,0 grams of wood mill was weighed and placed in the stainless steel combustion capsule. The combustion capsule containing the sample was then lowered in the wire bomb head while the bomb head was on its support. A ten centimetre long fuse wire was firmly fixed to the electrodes to facilitate complete combustion. Then $1 \mathrm{ml}$ of water was added to the bomb cylinder and the sealing ring of the bomb head was moistened. The bomb was carefully lowered into the cylinder and tightly closed with the sealing ring. To facilitate complete combustion $30 \times 10^{5} \mathrm{~N} / \mathrm{m}^{2}$ of oxygen was introduced into the combustion cylinder. The bomb cylinder was then lowered into the calorimeter bucket. The calorimeter cover was carefully placed and the thermometer bucket lowered. The power was then switched on to start the auto temperature adjustment and the stirring motor. The initial temperature was recorded after equilibrium was attained i.e. after 300 seconds. The bomb content was then fired using the ignition switch. The bucket temperature i.e. final temperature was recorded after it had stabilised i.e. after 300 seconds. The unburned fuse wire was straightened and its new length measured. The difference 
between the original length and the new length was multiplied by 2.3 to obtain the number of calories liberated by combustion of the fuse (fuse wire correction). For every sample, gross energy (calorific value) in $\mathrm{kcal} / \mathrm{g}$ was calculated using the following equation:

$$
C V=\frac{\Delta T \times K-w_{c}}{W_{s} \times 1000}
$$

Where: $\mathrm{CV}=$ Calorific value $(\mathrm{kcal} / \mathrm{g}) ; \Delta T=$ temperature rise; $K$ is the energy equivalent of the system that was used for the experiment $\left(2206,24 \mathrm{kcal} /{ }^{\circ} \mathrm{C}\right) ; \quad w_{c}$ fuse wire correction (kcal); $W_{s}=$ sample weight $(\mathrm{kg})$. The values were converted to $\mathrm{kJ} / \mathrm{kg}$ for ease of comparison.

\section{Cleavage resistance parallel to the grain}

Cleavage resistance tests were conducted using a Tinius Olsen Model H50K-T universal material strength testing machine. The experiment was carried out at constant loading rates and conditions in reference to BS 373(1957). Each test piece measuring $20 \mathrm{~mm}$ x $20 \mathrm{~mm} \times 45 \mathrm{~mm}$ was loaded at a constant cross head speed of $0.04 \mathrm{~mm} / \mathrm{second}$. The shear stress in $\mathrm{N} / \mathrm{mm}^{2}$ was directly recorded by Qmat professional software from the cross head. The test specimens were at $12 \pm 3 \%$ average $\mathrm{MC}$ at the time of the test.
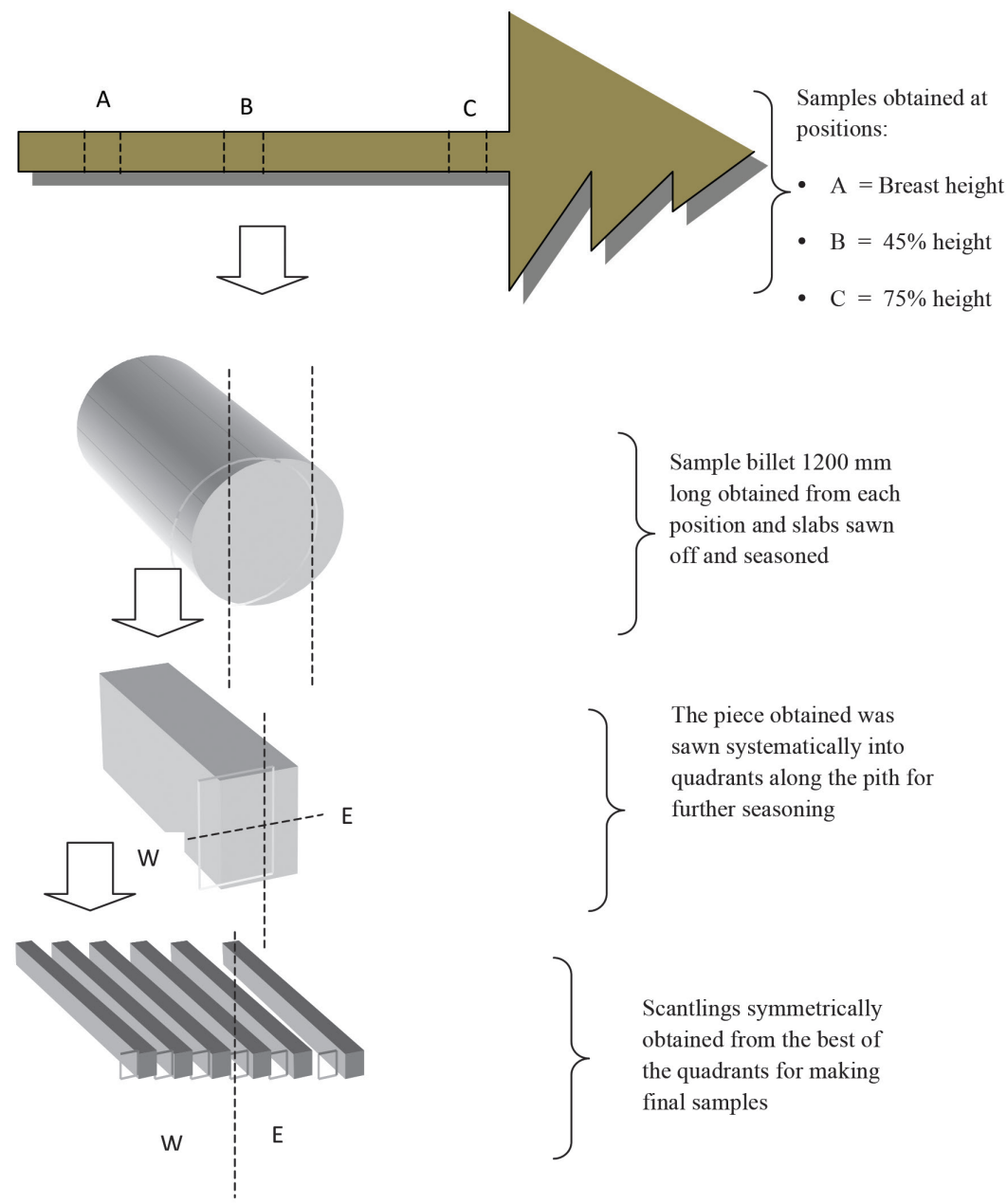

Sample billet $1200 \mathrm{~mm}$ long obtained from each position and slabs sawn off and seasoned

The piece obtained was sawn systematically into quadrants along the pith for further seasoning

Figure 2. Sampling within individual trees. 


\section{Data analysis}

Descriptive statistical procedures were used to obtain means and standards deviations for all test properties using SPSS. One-way ANOVA was used to assess the variation in test properties with site and position of sample within the tree (NIST/Sematech 2010). In order to accommodate the influence of natural variations within the trees and any other sources of variation during the experiment, order statics (percentiles) were used to generate a tolerance interval within which $90 \%$ of the measured properties of a given clone are likely to fall at $95 \%$ confidence level. Tolerance interval was computed according to equation (3)

\section{Tolerance interval $=$ Mean $\pm K_{2} S$}

where;

$\mathrm{S}=$ Standard Deviation

$$
\mathbf{K}_{2}=\sqrt{\frac{(N-\mathbf{1})(\mathbf{1}+\mathbf{1} / N) Z_{(1-p) / 2}^{2}}{X_{\gamma, N-1}^{2}}}
$$

Where $\mathrm{X}_{\gamma, \mathrm{N}-1}^{2}$ is the critical value of chi-square with degrees of freedom, $(\mathrm{N}-1)$ that is exceeded with probability $\gamma$ and $\mathrm{Z}_{(1-\mathrm{p}) / 2}$ is the critical value of the normal distribution which is exceeded with probability $(1-p) / 2$. Tolerance interval and mean values of each property were compared with the known values of parent material i.e. E. grandis, E. cammaldulensis and E. urophylla. 


\section{RESULTS}

\section{Clonal Eucalyptus mean properties}

The overall means of the tested properties of hybrid eucalypts independent of site, and position of the specimen with in the tree are presented in table1. Clone GC540 showed the highest mean basic density $\left(664 \mathrm{~kg} / \mathrm{m}^{3}\right)$ while GC550 had the lowest $\left(627 \mathrm{~kg} / \mathrm{m}^{3}\right)$. GU7 had the highest Calorific Value $(17800 \mathrm{~kJ} /$ $\mathrm{kg})$ and it was lowest in GC796 (16700 kJ/kg). GU7 and GC540 had higher mean values for cleavage resistance $(20 \mathrm{~N} / \mathrm{mm})$ than the other clones (Table 1).

Table 1. Showing means and tolerance (2 sided) interval for properties of clonal Eucalyptus planted in Uganda.

\begin{tabular}{|c|c|c|c|}
\hline CLONE & $\begin{array}{c}\text { Basic Density } \\
\left(\mathbf{k g} / \mathbf{m}^{3}\right)\end{array}$ & $\begin{array}{c}\text { Calorific Value } \\
(\mathbf{k J} / \mathbf{k g})\end{array}$ & $\begin{array}{c}\text { Cleavage Resistance } \\
(\mathbf{N} / \mathbf{m m})\end{array}$ \\
\hline GU7 & $654(580-728)$ & $17800(10223-25377)$ & $20(12-27)$ \\
\hline GU8 & $643(606-680)$ & $17500(11922-23078)$ & $19(11-27)$ \\
\hline GC540 & $664(602-727)$ & $17700(13686-21714)$ & $20(10-30)$ \\
\hline GC550 & $627(550-713)$ & $17500(14561-20439)$ & $18(10-26)$ \\
\hline GC796 & $652(569-735)$ & $16700(9355-24044)$ & $18(8-28)$ \\
\hline
\end{tabular}

Values in brackets: tolerance intervals

\section{Variation of wood properties with site}

Basic density significantly varied among the clones $(\mathrm{P} \leq 0,05)$ and also within and between sites GU8 ( $\left.\mathrm{F}_{1,68}=11,3 ; \mathrm{P} \leq 0,001\right)$; GC540 ( $\left.\mathrm{F}_{1,68}=10,42 ; \mathrm{P} \leq 0,002\right) ; \mathrm{GC} 550\left(\mathrm{~F}_{1,59}=5,92 ; \mathrm{P} \leq 0,02\right)$ and $\mathrm{GC} 796$ $\left(\mathrm{F}_{1,68}=19,93 ; \mathrm{P} \leq 0,001\right)$. It was significantly $(\mathrm{P}<0,05)$ higher in Ikulwe except for clone GC540 (Figure 2). Cleavage resistance was significantly $(P<0,05)$ higher for clones $G U 7\left(F_{1,63}=26,37 ; P \leq 0,000\right)$; $\operatorname{GC540}\left(\mathrm{F}_{1,63}=6,15 ; \mathrm{P} \leq 0,02\right) ; \mathrm{GC550}\left(\mathrm{F}_{1,59}=13,9 ; \mathrm{P} \leq 0,02\right)$ and $\mathrm{GC796}\left(\mathrm{F}_{1,58}=56,72 ; \mathrm{P} \leq 0.00\right)$ obtained from Ikulwe (Figure 3$)$. There were no significant $(\mathrm{P}>0,05)$ differences in Calorific values for clones obtained from the two sites.

\section{Variation of wood properties within individual trees}

Basic density increased significantly $(\mathrm{P}<0,05)$ along tree height for clones GU7 $\left(\mathrm{F}_{2,64}=4,07 ; \mathrm{P} \leq 0,02\right)$; GU8 $\left(\mathrm{F}_{2,67}=3,77 ; \mathrm{P} \leq 0,03\right)$ and $\mathrm{GC796}\left(\mathrm{F}_{2,67}=4,29 ; \mathrm{P} \leq 0.02\right)$ contrary to the known systematic variation in a tree i.e. it was expected to be higher in the butt end decreasing with height (Figure 4).Cleavage resistance decreased significantly $(\mathrm{P}<0,05)$ with height in clone GC550 $\left(\mathrm{F}_{2,58}=4.47, \mathrm{P} \leq 0.02\right)$ (Figure 5). However, there were no significant $(\mathrm{P}>0,05)$ differences within clones across the stem in relation to basic density, calorific value and Cleavage resistance. 


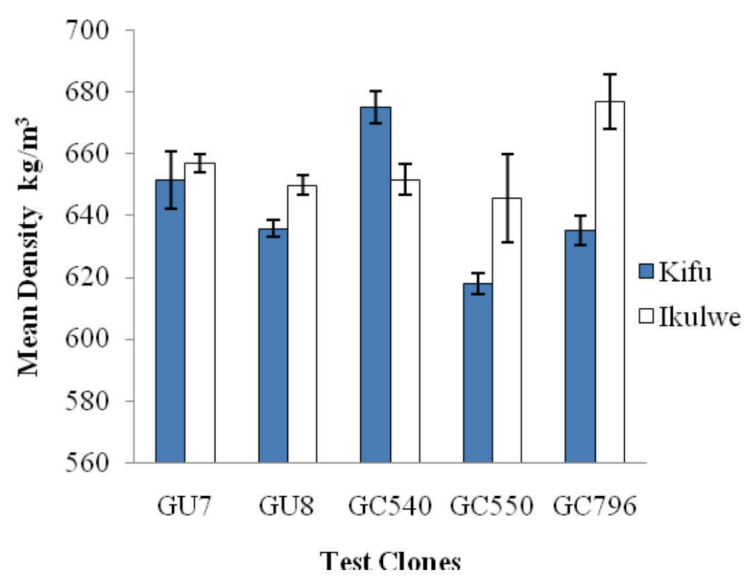

a)

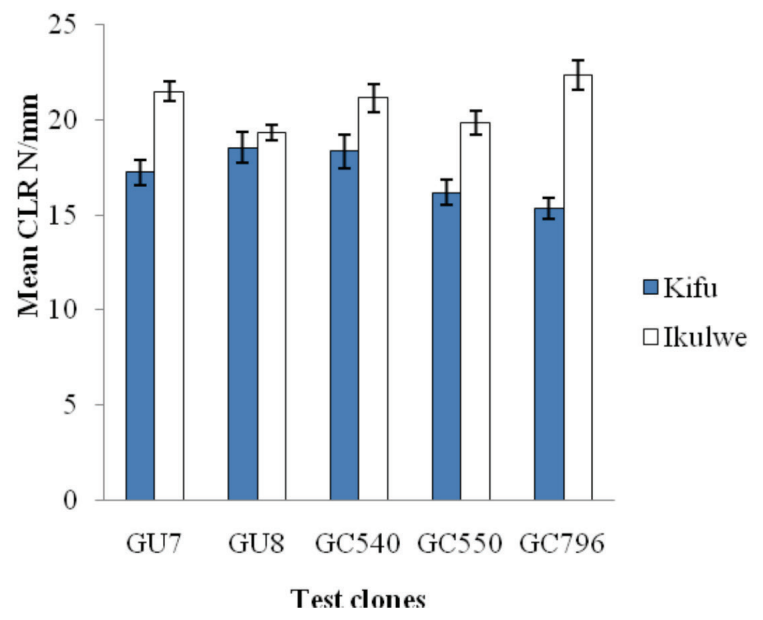

b)

Figure3. (a) Influence of growing site on Basic Density (b) Influence of growing site on Cleavage resistance of clonal eucalypts grown in Uganda since 2002. 


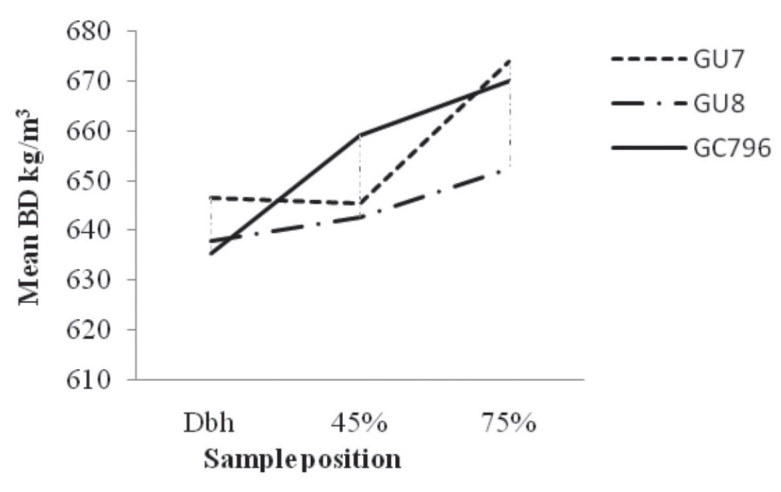

a)

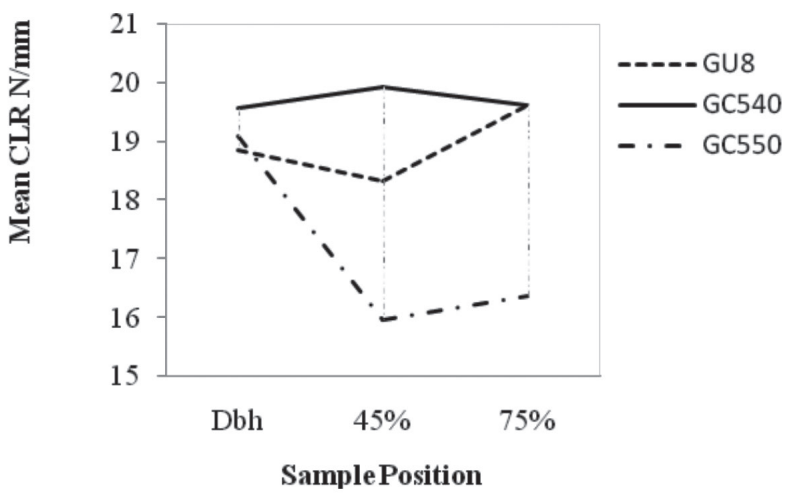

b)

Figure 4. (a) Variation of Basic Density along tree height and (b) Variation of Cleavage Resistance along tree height.

\section{Comparison of properties and prediction of potential end use of clonal timber}

Basic density (BD) and Cleavage resistance (CLR) values were intermediate between parental means especially for $\mathrm{GC}$ clones, with higher values than $E$. grandis and lower values compared to $\mathrm{E}$. cammaldulensis. The $\mathrm{BD}$ values for GU clones were higher than E. urophylla and closer to E. grandis values (Table 2). All clones tested had generally lower Calorific values (CV) compared to parent materials. The low values of CV could be probably due to the small heartwood proportion at this age and, therefore, little quantities of extractives accumulated. However, clonal timber at 6-7 years remains a viable option for fuel wood compared to parent materials since the differences in CV can be compensated by the superior volume increment of clones per unit time and moderate CLR values to facilitate easier splitting. 
Table 2.Comparison of wood properties of clones with properties parent materials at utilisable age (tolerance interval values)

\begin{tabular}{|c|c|c|c|c|c|c|c|c|}
\hline \multirow[b]{2}{*}{$\begin{array}{l}\text { Test } \\
\text { Property }\end{array}$} & \multicolumn{5}{|c|}{ Properties from this study } & \multicolumn{3}{|c|}{$\begin{array}{l}\text { Properties of parent } \\
\text { materials at utilisable age }\end{array}$} \\
\hline & GU7 & GU8 & GC540 & GC550 & GC796 & $\begin{array}{l}\text { E.grandis } \\
\text { PROTA }\end{array}$ & $\begin{array}{l}\text { E. Camaldulensis } \\
\text { PROTA }\end{array}$ & $\begin{array}{l}\text { E. Urophylla } \\
\text { PROSEA }\end{array}$ \\
\hline $\begin{array}{c}\text { Basic } \\
\text { Density } \\
\left(\mathrm{kg} / \mathrm{m}^{3}\right)\end{array}$ & $\begin{array}{c}654 \\
(580-728)\end{array}$ & $\begin{array}{c}643 \\
(606-680)\end{array}$ & $\begin{array}{c}664 \\
(602-727)\end{array}$ & $\begin{array}{c}627 \\
(550- \\
713) \\
\end{array}$ & $\begin{array}{c}652 \\
(569-735)\end{array}$ & $540-775$ & $680-980$ & $540-570$ \\
\hline $\begin{array}{c}\text { Calorific } \\
\text { Value } \\
(\mathrm{kJ} / \mathrm{kg})\end{array}$ & $\begin{array}{c}17800 \\
(10223- \\
25377) \\
\end{array}$ & $\begin{array}{c}17500 \\
(11922- \\
23078)\end{array}$ & $\begin{array}{c}17700 \\
(13686- \\
217140) \\
\end{array}$ & $\begin{array}{c}17500 \\
(14561- \\
20439) \\
\end{array}$ & $\left|\begin{array}{c}16700 \\
(9355-4044)\end{array}\right|$ & $\begin{array}{l}18100- \\
19400\end{array}$ & $17700-21000$ & - \\
\hline $\begin{array}{c}\text { CLR } \\
\mathrm{N} / \mathrm{mm}\end{array}$ & $\begin{array}{c}20 \\
(12-27)\end{array}$ & $\begin{array}{c}19 \\
(11-27)\end{array}$ & $\begin{array}{c}20 \\
(10-30)\end{array}$ & $\begin{array}{c}18 \\
(10-26)\end{array}$ & $\begin{array}{c}18 \\
(8-28) \\
\end{array}$ & $4-6$ & $16-33$ & \\
\hline
\end{tabular}

\section{DISCUSSION}

The differences in overall means of Basic Density (BD), Calorific Value (CV) and Cleavage Resistance (CLR) values within clones may be as a result of differences in the anatomy of wood from individual hybrids i.e. thickness of the cell wall, size and arrangement of intercellular spaces and vessels (FPL 2000). The influence of site on BD for several clones in Uganda was expected since biological materials such as wood reflect the conditions under which they grow (Thelandersson 2003, Desch and Dinwoodie 1996). The general variation can be attributed to the differences in altitude, rainfall and soils in the two agro-ecological zones (Wortmann and Eledu 1999). In addition, variation in BD can also be explained by the differences in the amount of cell wall and extraneous substances present in clonal wood from the two AEZ. The influence of site on BD was most expressed in clones GC540 and GC796 with the two seemingly site specific i.e. GC796 and GC540 preferring Ikulwe and Kifu respectively. The growing conditions in the two agro-ecological zones resulted in formation of different earlywood to latewood proportions in the two clones.

BD increased significantly along tree height in some clones, this behavior is in contradiction with systematic variation of wood properties along tree height which asserts that as a rule the heaviest wood is found at the base of a tree (Desch and Dinwoodie 1996). BD varied significantly along tree height especially among GU clones. This kind of variation can probably be explained by differences in cellular structure i.e. fibre length and diameter at different levels along the tree height of GU clones compared to GC clones. Since BD, CLR and CV did not vary in the radial direction it is probably because clonal wood at 6-7 years was largely juvenile despite the volume attained.

CLR varied significantly with site in four clones tested (GU7, GC540, GC550, and GC796). This can be explained by differences in arrangement and orientation of fibers leading to straight or spiral grain. The low CLR in GC550 and the variation with height can be explained by the presence of growth stresses due to its fast growing nature and differences in cellular arrangement.Cleavage resistance is an important property in practical use of wood as fuel, as it determines the ease of splitting. Wood with low 
cleavage resistance splits readily under a wedge force in a radial direction (Zziwa et al. 2006). The higher $\mathrm{BD}$, moderate CLR, competitive values of CV coupled with the high volumes gains of eucalypts clones at 7 years indicates that clones are a viable option for fuel wood for rural household energy security. Therefore, large scale adoption of clones, is likely to address Uganda's fuel wood demands and enhance conservation efforts through reduced dependence on dwindling natural resources for fuel wood.

\section{CONCLUSIONS}

The basic density of all clones was in the range $550-735 \mathrm{~kg} / \mathrm{m}^{3}$. GC540 had the highest mean basic density $\left(664 \mathrm{~kg} / \mathrm{m}^{3}\right)$ while GC550 had the lowest $\left(627 \mathrm{~kg} / \mathrm{m}^{3}\right)$.

The calorific value was falling in $10223-25377 \mathrm{~kJ} / \mathrm{kg}$ range. GU7 had the highest calorific value $(17800 \mathrm{~kJ} / \mathrm{kg})$ and it was lowest in GC796 $(16700 \mathrm{~kJ} / \mathrm{kg})$.

The cleavage resistance ranged between 8 and $30 \mathrm{~N} / \mathrm{mm}$. GU7 and GC540 had higher mean values for cleavage resistance $(20 \mathrm{~N} / \mathrm{mm})$ than the other clones

Although clonal wood had lower CV than parent materials, clonal timber at 6-7 years remains a viable alternative for fuel wood to parent materials since the differences in $\mathrm{CV}$ can be compensated by the superior volume increment of clones per unit time and better CLR values to facilitate better splitting especially of GC clones. This should be considered as important in Uganda and those other countries which rely heavily on wood fuel for energy. This also works as a conservation tool for the endangered indigenous forests because without wood alternatives like those from Eucalyptus clones, deforestation will have to be on increase as wood fuel is a must source of household energy for Uganda and several other developing countries.

In future we recommend that Properties of older trees such as those aged nine years and above should be studied to minimise effects of juvenile wood; and since some properties were influenced by site, it is prudent that adoption of clones in other regions be guided by studies of wood properties and silvicultural attributes in relation to the specific sites. 


\section{ACKNOWLEDGEMENTS}

We thank Development Partnerships in Higher Education (DelPHE) and Sawlog Production Grant Scheme (SPGS) for funding this study.

\section{REFERENCES}

ASTM, ASTM International. 2006. Standard Test Methods for Analysis of Wood Fuels. ASTM E870 - 82/2006. West Conshohocken Pennsylvania.

British Standards Institution. 1957. Method of testing small clear specimens of timber. British Standard No.373. London.

Desch, H. E.; Dinwoodie, J. M. 1996. Timber structure, properties, conversion and use, $7^{\text {th }}$ edition. Food products press, New York.

Epila-Otara, J. S.; Ndhokero, J. 2009. Selection and site matching of Eucalyptus clones in Uganda. Journal of East African Natural Resources Management 3 (1): 237-248.

Epila-Otara, J. 2004.Tree Biotechnology Project: Uganda's experience: In: Ngamau, C.; Kanyi, B.; Epila-Otara, J.; Mwangingo, P and Wakhusama, S., (Eds): Towards Optimizing the Benefits of Clonal Forestry to Small-scale Farmers in East Africa. International Service for the acquisition of AgriBiotechnology Applications (ISAA). Nairobi, Kenya. No. 33.

Forest Products Laboratory2000. Wood Handbook: Wood as an engineering material. Forest service U.S. Department of Agriculture. University Press of the Pacific.

NIST/Sematech. 2010. NIST/SEMATECH e-Handbook of Statistical Methods, [online ] <http:// www.itl.nist.gov/div898/handbook/ > [acesss July 25 2010].

Oballa, P.; Chagala-Odera, E.; Wamalwa, L.; Oeba, V.; Mutitu, E.; Mwangi, L. 2005. The performance of Eucalyptus Hybrid clones and local landraces in Various agro-ecological zones in Kenya. International Service for the acquisition of Agri-Biotechnology Applications (ISAA). Nairobi, Kenya.

Sawlog Production Grant Scheme. 2007. Tree Species for Commercial Timber Production and where they grow best in Uganda. Plantations Guidelines No. 5\& 6 - June 2007.

Thelandersson, S. 2003. Timber Engineering general introduction: In Thelandersson, S., and Larsen, H. J., (Editors) Timber Engineering. John Wiley \& Sons Ltd, Sussex, England. 
Tinius, O. 2003. QMAT Materials Testing and Analysis Software. Bulletin113. United Kingdom.

Wortmann, C.S.; Eledu, C.A. 1999. Uganda's Ecological Zones. A Guide for Planners and Policy Makers. CIAT, Kampala, Uganda. 56 p.

Zziwa A.; Kaboggoza J. R. S.; Mwakali .A.; Banana, A. Y.; Kyeyune, R. K. 2006. Physical and Mechanical Properties of Some Less Utilised Tropical Timber Tree Species Growing in Uganda. Uganda Journal of Agricultural Sciences 12(1):29-37. 